\title{
Countiy Risk Analysis of Pakistan: Evidence from Karachi Stock Exchange
}

\section{Sadia Saeed ${ }^{1}$, Fauzia Mubarik ${ }^{2}$}

1 Lecturer, National University of Modern Languages, Islamabad, Pakistan

2Assistant Professor, National University of Modern Languages, Islamabad, Pakistan

\section{A B S T R A C T}

This study analyzes the country risk of Pakistan by employing the international capital asset pricing model (ICAPM) framework for the time period of July 2000 to June 2015. This study has used the country beta approach to examine the country risk based on the local as well as the global economic indicators. The study includes one domestic variable; foreign exchange reserves (cash holdings) and three global variables; real foreign exchange rate, gold prices, and oil prices to examine the impact of these economic factors on country risk by employing Beta market approach. The empirical results of this study conclude that time varying beta in Pakistan is affected by the global economic factors as well as the domestic economic factors and hence support the international capital asset pricing model in case of Pakistan. The findings of the study suggest that the international investors can frame out the hedging policy against country risk in measuring investment return and that an effective monetary and fiscal policy can be designed by considering the relationship of macroeconomic factors with country risk.

JEL Classification: G10, G15

KEYWORDS: World Market Index, Economic Factors, Multiple Regression Model, Global factors, Country Beta,

\section{INTRODUCTION}

The investment behaviors of the international investors differ while investing in the emerging economies than in the developed economies. These investors are sensitive to both the local as well as the foreign fundamental economic conditions while investing in the emerging markets whereas consider only the local economic conditions while investing in the developed markets and further prefer only to invest in the local denominated securities respectively.

Globalization and cross border investments have induced uncertainty in the rate of return earned on foreign investments because of the risks related to the international 
operations and productions management vulnerable to the adverse economic conditions. Such risk is called the country risk that depicts the financial conditions of a respective country to satisfy its international financial liabilities respectively. Country risk basically is the composite of the political and the economic factors that realizes the financial status of a country in the respective international community.

Since few years, Pakistan has become attractive for the international investors because of various economic developments. Since the early 1990's, many capital markets reforms are initiated by the Securities and Exchange Commission of Pakistan (SECP) to boost up the economic growth of the country and is taking certain measures to ensure that the capital market is functioning according to the set principles such as the investment doors have been opened to the international investors with $100 \%$ ownership in an enterprise, permission to the foreign investors to open the private investment and commercial banks, complete repatriation facility to the foreign investors who make investments in Pakistan, and the privatization of the local banks and institutions. Some of the other key factors that have positively contributed to the growth of the Pakistani economy are the continuous thrive for the sufficient liquidity position in the financial markets, the modern technological developments in the stock market and demutualization of the three stock markets, exchange rates stability, big acquisitions and mergers, recovery of foreign loans, decrease in the interest rates offered by banks and the proper regulatory mechanisms set by the Securities and Exchange Commission of Pakistan (SECP).

According to Euler and Hermes country risk analysis is a challenge for emerging markets due to insufficient and unreliable statistical data. Country beta model is the method to quantitatively measure the country risk of a country. According to this model, the difference between country equity returns and world equity returns is referred as the country risk. The country beta model has been first presented theoretically in seminal papers by Erb, Harvey, and Viskanta (1996-B). Later on, this model has been empirically tested by Gangemi, Brooks, and faff (2000) in Australia and Verma and Soydermir (2006) in Brazil. This research is an attempt to quantitatively measure the country risk of Pakistan by employing a country beta approach which has not been sufficiently empirically modeled 
and analyzed before. Secondly, it tries to select those economic factors on a daily basis that may identify the business conditions of the country. Thirdly, this research employs domestic as well as global economic factors in country risk analysis of Pakistan in international asset pricing model (ICAPM) framework which is the extension of capital asset pricing model (CAPM) respectively. The ICAPM estimates risk and return internationally and measures correct return for investors. Lastly, this study attempts to further find out that which of the economic variables either domestic or global are more relevant in country risk assessment of Pakistan.

\section{LITERATURE REVIEW}

This section reveals various definitions of country risks stated by various researchers in the theoretical literature of risk management. It also discusses different methodologies used by researchers for country risk assessment and studies conducted on analysis of country risk in empirical literature of risk management.

Krayenbuehl (1985) described country risk is the chance of default in the repayment of borrowers obligation to lenders in the foreign country. Shanmugam (1990) illustrated country risk as the inability of a country to repay its foreign obligation due to inadequate foreign reserves. Shapiro's view (1999) is different from the above two researchers. He defined country risk as an investment in a country is being affected by instability in its political and economic conditions. Country risk, political risk, and sovereign risk are usually considered as identical but these three risks have different meanings.

Kobrin (1979) illustrated political risk in detail. The risk associated with unfavorable political conditions of a country refers to political risk. When the political decisions of one country affect the profitability of the business or projected worth of a certain economic achievement, the form of risk faced by governments, organizations, and investors is termed as political risk. Brewer and Rivoli (1990) demonstrated the concept of Sovereign risk. The risk in the repayment of the foreign loan is stated as Sovereign Risk. Foreign loan refers to the loan taken by the Government or the loan guaranteed by Government. 
The political, economic and financial instability of a country originates country risk. Therefore country risk is a wide form of the risk as it encounters political, financial and economic risk. Moreover, these three risks affect each other and are considered as three main components of country risk. Different researchers used one, two and all the components of country risk to measure it quantitatively

Nagy (1988) quantitatively measured the credit risk by taking its social and economic components. He used a sharp increase in the cost of production, inefficient utilization of foreign loans, inappropriate foreign lending and non-smooth terms of country's trade for measuring country risk. Ghose (1988), Shanmugam (1990) have identified political risk contributed a lot towards country risk. The country risk will be higher for that country whose neighboring country is at war. Brewer and Rivoli (1990) tested political instability and perceived creditworthiness of a country. They encountered political, economic and financial factors in the assessment of country risk. Political, economic and social dimensions show that country risk is a global risk. Jeon (2001) also explored the impact of macroeconomic factors on country risk in 14 developed countries by using country beta approach model. He used U.S term premium, industrial production index, consumer price index, U.S default premium and weighted exchange rate. The research depicted that country betas in developed countries are most affected by industrial production index, consumer price index and weighted exchange rate.

Country risk rating system measures the creditworthiness of a country either country is able to pay its debt regularly or not. Ribeiro (2001) have identified certain economic factors that are considered standard for measuring country risk by rating agencies. These factors are based upon financial obligations of a country such as exchange rate, interest rate, money supply, inflation rate, import, export, debt services, and repayments of loans, GDP, GNP, flow of foreign loans, direct investment and external debt. Moreover, Vij (2005) employed Eurom and institutional investor's country risk rating to test the impact of political and economic factors on it. He predicted that the impact of political risk on country risk rating is significant and the contribution of two macroeconomic factors GNP per capita and gross capital formation towards country risk 
rating is more as compared to other macroeconomic factors. Vij and Kapoor (2007) also tested the association of political, macroeconomic and financial factors on country risk rating. They found all the factors political, macroeconomic and financial measured credit risk rating. The creditworthiness of a country is based upon repayment of financial obligations smoothly and this could be possible through high growth rate in export. Therefore macroeconomic factors economic growth rate, current account balance and financial factors such as external debt, debt payments; interest payments and Savings to investment ratio have the main contribution towards assessment of country risk. Moreover, Political stability enhanced the capability of a country to service its debt easily.

Verma and Soydemir (2006) showed the influence of local and global macroeconomic factors on country risk of Chile, Argentina, Mexico, and Brazil. Among local macroeconomic indicators, money supply and exchange rate contributed mainly towards country risk. On the other hand global macroeconomic factors such as real interest rate and inflation rates of $\mathrm{G} 7$ countries have a statistically significant negative impact on country betas. Teixeira, Klotzle, and Ness (2008) also examined the varying degree of influence of domestic and external economic factors in Brazilian country risk. They used GDP growth, Fiscal surplus, public debt, inflation rate, current account surplus, external debt and international reserves in their research. They tested the relationship between domestic \& external economic factors and total country risk. They also demonstrated the long term and short term relationship between specific risk and economic factors by using ARDL approach. They found that external economic factors have a strong impact on Brazilian credit risk.

Basu, Deepthy, and Reddy (2011) employed Beta country risk model of Andrade and Teles (2004) to identify the most relevant economic factors in explaining the country risk of India. They used Exchange rate, Unemployment rate, FDI, and interest rate and found that significant correlation exists between variation in country risk and macroeconomic indicators. Moreover, they also studied the impact of political risk on country risk. Glova (2014) also investigated a country beta model in CAPM framework to examine which macroeconomic factors are more relevant in country risk analysis of 
CESEE countries. CESEE countries include Bulgaria, Poland, Romania, Latvia, Lithuania, Hungary and.The Czech Republic. He found the influence of global risk factors in country risk assessment is more as compared to local risk factors. Naumoski (2012) worked on asset pricing and country risk in emerging markets and found that investors considered country risk is a key component in estimating the cost of capital.

Verma (2014) analyzed ICAPM model to examine domestic and global economic factors in country risk analysis. They generated country betas of Hong Kong, Singapore, Philippines, Indonesia, and Malaysia. Regression results showed that global factors in measuring country risk are dominant over local factors.

The present research is the extension of literature in distinct ways. Firstly, it determines the country beta of Pakistan which has not been sufficiently determined before. Secondly, this research employs domestic as well as global economic factors in country risk analysis of Pakistan in ICAPM framework. The research also tests which economic variables either domestic or global is more relevant in country risk assessment of Pakistan. As Pakistan is an emerging market, therefore, the selection of domestic as well as global economic variables is based upon the literature of equity returns of emerging markets respectively.

This study includes only one domestic variable in the study due to the nonavailability of computerized data on daily basis respectively. This study can be extended by including more domestic variables on daily basis to further compare the significance level of the domestic as well as the international economic variables on the country beta in case of the Pakistani market.

\section{Hypotheses}

This research has been conducted to test the following hypotheses.

H1= Domestic Factor has no significant impact on country risk.

Ha1= Domestic Factor has a significant impact on country risk.

$\mathrm{H} 2=$ Global Factor has no significant impact on country risk.

$\mathrm{Ha} 2=$ Global Factor has a significant impact on country risk. 


\section{RESEARCH METHODOLOGY}

This study comprises of four economic variables on a daily basis that commonly affects the discount rate and the dividend stream of the stocks (Poterba and Summers, 1988) and describes the business conditions in Pakistan (Economic Survey of Pakistan, 20002015) respectively. The country beta is taken as a proxy for the covariance of the world market index and the Karachi Stock Exchange (KSE 100) index respectively.

\section{Sample Data:}

The set of economic variables includes; market return, foreign exchange reserves (cash holdings), real foreign exchange rate, oil prices and gold prices for the time period of July 2000 to June 2015 on daily basis. The data for the market return and real foreign exchange rate is collected from the published manual of Economic Survey of Pakistan and the data for the foreign exchange reserves (cash holdings) is taken from the website of State Bank of Pakistan. The data for the oil prices and the gold prices are collected from the websites respectively.

The stock market return indicates the Karachi stock market index (KSE-100 index) of Pakistan. The foreign exchange reserves (cash holdings) are the reserves held by the central bank of Pakistan and the banks of Pakistan respectively. The motive behind these reserves is the stability of the Pak-Rupee currency and to hedge any economic shock that may encounter the country. This study has taken into account only the cash holdings as the gold prices are taken as a separate variable for the analysis of the present study. Under the foreign exchange regulation act of 1947, the State bank of Pakistan is responsible to regulate the foreign exchange market in Pakistan. Currently, the exchange rate of PakRupee per US dollar is determined by the demand and supply of the Pak-Rupee per US dollar under the freely floating exchange rate determination system prevailing in Pakistan respectively. According to Ghosh et.al (2002), amongst the commodity investments, the safe investment is found to be in gold because of its advantage of high liquidity and lack of default risk respectively. This study has taken the data on the gold prices in Pak-Rupees of 24 karats per gram respectively. Lastly, oil is another economic variable of the study. 
Pakistan's crude oil needs are majorly fulfilled through imports and the data for the oil prices are taken in Pak-Rupees respectively.

\section{Methodology:}

Verbenik et al (2011) demonstrated that international investment activities and country risk are related to each other and foreign investor faced country risk when he or she invests in that country. Capital asset pricing model (CAPM) developed in 1970,s show the relationship between risk and return. The relationship between return on market and return on investment has originated the risk. It is measured by Beta $(\beta)$. In early eras, many researchers have been performed to relate firm specific factors to the beta of investment. In this simple beta model, CAPM has been employed to estimate beta. Harvey (1991) attempted to relate CAPM with country risk and introduced Beta market model. In Beta market model beta is time varying and a function of various economic, financial and political factors.

According to Toma et.al (2014), some of the fundamental economic risk factors are the macroeconomic factors, fiscal policy, monetary policy, inflation and budget deficit, investment policy that influence the economy as well as the political conditions of a country respectively. Therefore, this research study includes one domestic variable; foreign exchange reserves (cash holdings) and three global variables; real foreign exchange rate, Gold prices, and Oil prices to examine the impact of these economic factors on country risk by employing Beta market approach.

Following Muwando and Gumbo (2013), the economic factors are estimated as the function of the country beta as shown below;

$$
\beta_{\mathrm{t}}=\mathrm{f}(\mathrm{fxr}, \mathrm{ex}, \mathrm{oil}, \mathrm{gold})
$$

Where $\beta \mathrm{t}$ represents the country beta computed as;

$$
\begin{aligned}
& \left.\beta_{\mathrm{t}}=\underline{\text { Covariance }(\mathrm{KSE} 100 \text { index daily returns }}{ }_{t} \text {, World market index daily returns }{ }_{\mathrm{t}}\right) \\
& \text { Variance (World market index daily returns) }
\end{aligned}
$$

And $\mathrm{f}$ represents the function of foreign exchange reserve (cash holdings), real foreign exchange rate, oil, and gold respectively. 
To analyze and model the impact of the economic variables on country beta, the multiple regression models are used for the estimation process as shown below;

$$
\beta_{\mathrm{t}}=\alpha \mathrm{o}+\alpha 1 \mathrm{fxr}(\mathrm{ch})+\alpha 2 \mathrm{ex}+\alpha 3 \text { oil }+\alpha 4 \text { gold }+\varepsilon_{\mathrm{t}}
$$

Where $\alpha o$ represents the tern intercept of country risk, $\alpha 1, \alpha 2, \alpha 3$, and $\alpha 4$ represents the regression coefficients and $\varepsilon_{\mathrm{t}}$ represents the error term respectively.

All of the economic variables are calculated by taking the first difference natural logarithm of Karachi Stock Exchange 100 index, the foreign exchange reserves (cash holdings), real foreign exchange rate, oil price and gold prices of Pakistan as shown below;

$$
R_{e}=\ln \left(p_{t}\right)-\ln \left(p_{t-1}\right)
$$

Where Re indicates the return of the respective economic variable, In indicates the natural logarithm, $\mathrm{p}_{\mathrm{t}}$ indicates current day market price and $\mathrm{pt}-1$ indicates the previous day price of the stock market.

As the economic variables do time-dependent possess random-walk properties? Therefore, the financial and economic variables are stationaries by the Augmented DickeyFuller test expressed;

ADF Test

$$
\begin{aligned}
\Delta y_{t} & =\gamma \mathrm{y}_{\mathrm{t}-1}+\sum_{\mathrm{i}=1}^{\mathrm{p}} \beta_{i} \Delta \mathrm{y}_{\mathrm{t}-1+} e_{t} \\
\Delta y_{t} & =\propto_{0}+\gamma \mathrm{y}_{\mathrm{t}-1}+\sum_{\mathrm{i}=1}^{\mathrm{p}} \beta_{i} \Delta \mathrm{y}_{\mathrm{t}-1+} e_{t} \\
\Delta y_{t} & =\mathrm{n}_{0}+\gamma \mathrm{y}_{\mathrm{t}-1}+\mathrm{n}_{0} \mathrm{t}+\sum_{\mathrm{i}=1}^{\mathrm{p}} \beta_{i} \Delta \mathrm{y}_{\mathrm{t}-1+} e_{t}
\end{aligned}
$$

Where $\Delta \mathrm{yt}-1$ is a stationary process and it is a white noise process.

The Ljung-Box statistics LB (10) and LB2(10) Kavocic (2008) is employed to test for the autocorrelation and squared autocorrelation expressed;

$$
\mathrm{Q}(\mathrm{K})=T(T+2) \sum_{k=1}^{k}\left(\frac{\widehat{p^{2}} k}{T-K}\right)
$$

Where $\mathrm{K}$ indicates the lag length, ${p_{k}}^{2}$ is the sample autocorrelation coefficient of order $\mathrm{k}$. This statistic follows a chi-square distribution with $\mathrm{K}$ degrees of freedom.

\section{RESULTS AND DISCUSSION}

Before initiating the estimation process, the series is turned stationary by using the Augmented Dickey-Fuller (ADF) test because the daily time series data of economic 
variables and country beta has been used in the respective research. The results report that the world market closing prices, real foreign exchange rate, foreign exchange reserve (cash holdings) rate, gold prices, and oil prices are stationary at the trend and intercept at first difference $\log$, therefore log first difference of the respective local and global economic variables are used for the estimation process. The results are reported in the appendix. Moreover, Unit root test is verified by t- statistic (1.99) of Durbin Watson in table 3. It means there is no serial correlation in the respective data.

\section{Descriptive Statistics:}

Table 1 illustrates the descriptive statistics of economic variables of the research. The economic variables included in the research are Exchange rate, Oil prices, Foreign Exchange Reserves, Gold. The table shows the average of each variable used in the research. The kurtosis values of economic variables are above or near to three showing leptokurtic distribution. It means values are concentrated around the mean and show the elevated probability of extreme values. Exchange Rate, gold, and oil are positively skewed and Exchange rate reserve is negatively skewed.

\begin{tabular}{|c|c|c|c|c|c|c|c|}
\hline $\begin{array}{c}\text { Economic } \\
\text { Variables }\end{array}$ & Mean & Std.Dev. & Skewness & Kurtosis & Jarque-Bera & Prob. & Obs. \\
\hline K Fxr(ch) & 0.88 & 0.56 & -0.20 & 2.29 & 766.9 & 0.00 & 2220 \\
\hline EX & 0.07 & 0.19 & 0.37 & 7.66 & 848.9 & 0.00 & 2227 \\
\hline Oil & 0.28 & 0.49 & -0.92 & 1.36 & 419.63 & 0.00 & 2215 \\
\hline Gold & 0.75 & 0.56 & -0.20 & 3.29 & 331.58 & 0.00 & 2197 \\
\hline
\end{tabular}

Table 1: Descriptive statistics

\begin{tabular}{|l|l|l|l|l|}
\hline \multicolumn{1}{|c|}{ Independent Variables } & Exchange Rate & Oil & \multicolumn{1}{|c|}{ Gold } & $\begin{array}{l}\text { Foreign exchange } \\
\text { reserves }\end{array}$ \\
\hline Exchange Rate & 1 & & & \\
\hline Oil & 0.054694575 & 1 & & \\
\hline Gold & 0.067394921 & 0.086259 & 1 & \\
\hline Foreign Exchange Reserves & 0.35783405 & 0.080115 & 0.071609 & 1 \\
\hline
\end{tabular}

Table 2 indicates that there all the independent variables are positively related to each other. The intensity of the relationship between all the variables is weak and the correlation coefficient of all the independent variables are less than 0.8 , therefore, there is no problem of multicollinearity in data. All the independent variables are included in the research for analyzing the country risk in Pakistan using Beta model. 


\begin{tabular}{|c|c|c|}
\hline Economic Factors & t-Statistic & Probability \\
\hline Constant & $\begin{array}{c}0.175 \\
(1.08)\end{array}$ & 0 \\
\hline EX & $\begin{array}{c}0.88 \\
(1.73)^{* *}\end{array}$ & 0 \\
\hline FXR & $\begin{array}{c}0.98 \\
(1.88)^{*}\end{array}$ \\
\hline OIL & $\begin{array}{c}0.79 \\
(-1.617)^{* * *}\end{array}$ & 0 \\
\hline GOLD & $\begin{array}{l}0.061 \\
(1.25)\end{array}$ & 0.0015 \\
\hline \multicolumn{2}{|c|}{ Pre Specification measures } \\
\hline R2 & 0.607 & 0.801887 \\
\hline Adj. $\mathrm{R}^{2}$ & 0.61 & \\
\hline Durbin Watson & 1.99 & 0.00014 \\
\hline F-Stat & 0.277 & \\
\hline
\end{tabular}

Table 3: Regression analysis

Table 3 illustrates that all the variables except gold are statistically significant. The Probability of F-statistics is less than .05 indicating that economic factors have a significant impact on country beta. If economic factors are analyzed individually, the result shows domestic factor Foreign Exchange Reserves has a statistically significant impact on country risk assessment. Similarly, global factors such as Exchange Rate and Oil prices are significantly measuring the country risk and reject the null hypothesis. Any change in domestic and global variables brings positive variation in country risk. Adjusted R2 of the model is 0.61 showing the contribution of economic variables towards the measurement of country risk is $61 \%$. Pakistan is an emerging market and it is highly volatile A lot of macroeconomic variables may bring variation in country risk of Pakistan but our research has included those variables whose daily data could be easily taken The research is different from the previous researchers in the sense that most researchers conducted on annual, monthly and quarterly basis in country risk analysis. The impact of daily statistics is different as compared to periodic intervals (monthly, annually, quarterly) in the highly volatile market.

The results of research are consistent with previous researches conducted by Verma and Soydemir (2006) Teixeira, Klotzle and Ness (2008) and Verma (2014) that Economic variables either domestic or global both are involved in the assessment of country risk in Pakistan. 


\section{CONCLUSION}

The research is an attempt to examine the contribution of domestic and global economic factors in analyzing the country risk of Pakistan by employing Market Beta Approach. Daily data of local and international economic factors have been used from 2000-2015 to quantify the response of country risk through variation in economic factors. A time varying country beta of Pakistan has been calculated and examined the impact of local and international economic factors on country beta. Regression result revealed that global factors and local factors both are contributed to the assessment of country risk. The local and global factors Foreign Exchange Reserves, Foreign Exchange Rate and Oil prices are statistically significant and have positive effects on country beta. The contribution of foreign exchange reserve to country beta is highest. The Global factor, gold is positively related to country beta but it is statistically insignificant. Empirical results of the research conclude that time varying beta in Pakistan is affected by global and local economic factors.

The research has many future implications. Foreign investors may consider economic risks specific to a country while investing in that country. Moreover, International investors can frame out the hedging policy against country risk in measuring investment return. An effective monitory and fiscal policy can be designed by considering the relationship of macroeconomic factors with country risk.

The current research can be extended by using more domestic and global variables to model and analyze the country beta model of Pakistan. Moreover, the comparative analysis may also be conducted by using the same domestic and global variables of the emerging markets with Pakistan.

\section{REFERENCES}

Basu, S., Deepthi, D., \& Reddy, J. (2011). Country Risk Analysis in Emerging Markets: The Indian Example. IIM Bangalore Research Paper, (326).

Brewer, T. L., \& Rivoli, P. (1990). Politics and perceived country creditworthiness in international banking. Journal of Money, Credit and Banking, 22(3), 357-369.

Erb, C. B., Harvey, C. R., \& Viskanta, T. E. (1996). Expected returns and volatility in 135 countries. Available at SSRN 871253.

Gangemi, M. A., Brooks, R. D., \& Faff, R. W. (2000). Modeling Australia's country risk: a country beta approach. Journal of Economics and Business, 52(3), 259-276.

Ghose, T., K. (1988). How to Analyze Country Risk", Asian Finance pp.61-63. 
Ghosh, D., Levin, E. J., Macmıllan, P., \& Wright, R. E. (2002). Gold as an inflation hedge? University of St. Andrews, Department of Economics. Discussion Paper Series.

Glova, J. (2014). Country Risk in the CESEE Countries: A Fundamental Beta Approach. Procedia Economics and Finance, 15, 100-107.

Hammer, P. L., Kogan, A., \& Lejeune, M. A. (2004). Country risk ratings: Statistical and combinatorial nonrecursive models. Rutgers University Center for Operations Research.

Harvey, C. R. (1991). The world price of covariance risk. The Journal of Finance, 46(1), 111-157.

Jeon, B., M. (2001). "Macroeconomic Influences on Country Risk". Working paper, Rice University.

Kavocic, Z. (2008). Forecasting Volatility: Evidence from the Macedonian Stock Exchange, International Journal of Finance and Economics, (18).

Kobrin, S. J. (1979). Political risk: A review and reconsideration. Journal of international business studies, 10(1), 67-80.

Krayenbuehl, T., E.(1985). "Country Risk: Assessment and Monitoring", Lexington Books report, US Infrastructure Report 2011, Business Monitor International Ltd., pp.141-153.

Muwando, S., \& Gumbo, V. (2013). Country Risk Model for Zimbabwe. Available at pspchv. com.

Nagy, P., J. (1988). "Country Risk: How to assess, quantify and monitor it”, London: money Publications.

Naumoski, A. (2012). Estimating the country risk premium in emerging markets: the case of the Republic of Macedonia. Financial Theory and Practice, 36(4), 413-434.

Poterba, J. M., \& Summers, L. H. (1988). Mean reversion in stock prices: Evidence and implications. Journal of financial economics, 22(1), 27-59.

Ribeiro, R., D.(2001), "Country Risk Analysis", GWU-IBI- MINERVA PROGRAM.

Shanmugam, B. (1990). Evaluation of political risk. Bourke, P. and Shanmugam, B.,(1990) An Introduction to Bank Lending, Addison-Wesley Business Series, Sydney.

Shapiro, A. (1999). "Multinational Financial Management" 6th ed., Prentice Hall, London.

Teixeira, M. F., Klotzle, M. C., \& Ness-Jr, W. L. (2008). Determinant factors of Brazilian country risk: an empirical analysis of specific country risk.Revista Brasileira de Finanças, 6(1), 49-67.

Teles, V., \& Andrade, J. (2008). Monetary policy and country risk. Applied Economics, 40(15), 2021-2028.

Toma et al. (2013). Country risk analysis: political and economic factors. University "Dunarea de Jos" of Galati.

Verbenik, M., Horváth, J., \& Gazda, V. (2011). Country risk in the new EU member states a country beta approach. International Research Journal of Finance and Economics, 80, 148-157.

Verma, R., \& Soydemir, G. (2006). Modeling country risk in Latin America: A country beta approach. Global Finance Journal, 17(2), 192-213.

Vij, M. (2005). The determinants of country risk analysis. Journal of Management Research, 5(1), 20-31.

Vij, M., \& Kapoor, M. C. (2007). Country risk analysis: A case study of India.Journal of Management Research, 7(2), 87.

\section{APPENDIX}

Unit Root Test

\begin{tabular}{|c|c|c|}
\hline Economic Variables & Level & First difference \\
\hline Rworld & $-2.181^{*}$ & $-11.40^{*}$ \\
\hline EX & -1.02 & $-4.16^{*}$ \\
\hline Fxr(ch) & -2.70 & $-6.70^{*}$ \\
\hline Oil & -1.65 & $-11.17^{*}$ \\
\hline Gold & -1.62 & $-13.11^{*}$ \\
\hline
\end{tabular}

